\title{
DANCING THE BODY OF GOD: \\ RITUALS OF EMBODIMENT FROM THE CENTRAL HIMALAYAS
}

Aditya Malik

\begin{abstract}
One of the important and wide-spread ways in which divinity is manifested in South Asia is through the enactment of religious rituals described in scholarly studies as inducing 'possession' through deities who then speak through the medium of 'possessed' devotees. My intention in this paper is to begin to create a shift in scholarly discourse that describes religious rituals that are conducted in order to invoke the presence of a deity, in terms of the categories of spirit 'possession' or trance, to a notion of embodiment or rather embodied consciousness. In my attempt to create a hermeneutics of embodiment for religious rituals that are commonly analysed in terms of possession, I draw on the Hindu deity Shiva's 'dance of rapture', as well as on the notion of embodiment as being the existential ground of possibility for culture and self. My arguments are based on materials gathered from recent preliminary field research into the narratives and rituals of the Central Himalayan deity Goludev.
\end{abstract}

\section{INTRODUCTION}

Supernatural or divine power is manifested through a variety of means and locations in South Asia: through temple rituals, at pilgrimage sites, through the actions of holy men and women, in the recitation of scriptures and so on. One of the enduring and predominant ways in which divinity is manifested is also through the enactment of religious rituals that induce 'possession' through deities who then often speak through the medium of 'possessed' devotees. While the study of possession in South Asia has a long history dating back to the first European missionaries in India in the early $18^{\text {th }}$ century (Ziegenbalg $1926[1711])$, the scholarly literature on possession often continues to locate its analysis within the parameters of Western situated explanatory models that often contain in-built prejudices toward the phenomenon. 
Within a more reflexive and sympathetic model that attempts to move away from psychological and sociological explanations, possession and possession rituals are described as a culturally constituted 'system of beliefs and practices' (see Freeman 1993). From this latter perspective it becomes important to engage fully with the cultural interpretations offered by the actors involved in the phenomenon of possession, rather than reducing their discourses and practices, for example, to psycho-pathology. However, even the claim that possession belongs to a 'system of beliefs and practices', raises the question of the relationship between belief and possession. For example, is this relationship one of cause and effect? Are beliefs the necessary (a priori) pre-condition for the activity of possession to take place? Moreover, is there a need to postulate the existence of beliefs at all when encountering South Asian materials, since the category of 'belief' itself is laden with centuries of theological and philosophical debate stemming from Christian / Western cultural traditions? Similarly, is the category of 'possession', given its long history of religious and cultural bias, an adequate term for describing rituals in which divine power is manifest in devotees?

Rich Freeman raises similar questions while describing an extremely elaborate, if not from an outside perspective 'exotic', possession ritual called Teyyam from the southern Indian region of Kerala:

To the foreign observer, performers engaged in the worship of Northern Kerala's Teyyam deities appear perhaps deranged, as though in the grip of some potentially violent fantasy. Rattling ornaments and clattering weapons, their limbs tremble in the monstrous forms which costume their bodies. They glower menacingly from floridly painted faces, then suddenly burst into hoarse shrieks directed to unseen beings. They swagger, whirl, and lunge into the onlookers, who scatter before their brandished sabers. Elsewhere, priests reel in the ambit of a raging bonfire, their eyes fixed on the swords which dance in their hands and seem to jerk them spasmodically through their movements. Assistants retrain them from doing harm, while worshippers look on in glassy awe (Freeman 1993:109).

Freeman points out that 'the indigenous perception is that these dancers and priests are "possessed" by their Teyyam deities' (Freeman 1993: 110). Although such rituals seem to be an enduring feature not only of south Indian culture but also western, eastern and northern India and there is a growing scholarly interest in such rituals, Freeman states that: 
the anthropological analysis of possession complexes are generally hampered by two methodological problems: the overly hasty move to reduce possession to Western models of psychological pathology, on the one hand, and to those of social-structural function (or dysfunction), on the other. Such approaches are especially problematic to the extent that they pre-empt cultural expositions given by the informants themselves in favour of a prior commitment to some particular social-scientific paradigm (Freeman 1993:110).

With this 'methodological trap' in mind Freeman states that his primary task is concerned with the 'representation of how possession as a system of belief and practice is culturally constituted (in Teyyam)' ( Freeman 1993: 111).

While Freeman's approach to possession is critical, reflexive, and sympathetic to its cultural context, the point that I will take up here for discussion concerns his concluding statement regarding possession as a system of belief and practice. What are the theoretical and cultural implications of using the category of belief in this context? While anthropologists themselves may not - due to their own cultural contexts or due to a scientific or rational attitude-harbour a belief concerning the reality of possession as a religious experience, they are willing to engage in the beliefs that others might have with regard to possession. My contention here is that postulating the existence of beliefs in the context of possession results in a hermeneutic distanciation based on the difference between knowledge and belief. While scholars possess knowledge, practitioners and participants of possession rituals possess beliefs. Rarely, do we encounter anthropologists describing possession as a 'system of knowledge and practices'. For example, Elisabeth Schömbucher in her recent work on possession amongst the fisher community of the Vadabalija in Orissa in Eastern India, raises a similar point:

The cultural translation of possession always implies the desacralization of the phenomenon... While from the indigenous perspective [possession has to do with] divine presence and divine speech, from the outside perspective it has symbolical meaning. [Possession] is not real or true, it is only the expression of a particular world-view... (Schömbucher 2006: 430; transl. from the German original).

Given this particular prejudice toward possession, my intention here is to begin to create a shift in scholarly discourse from describing religious rituals that are conducted in order to invoke the presence of a deity, in terms of the categories of spirit 'possession' or trance, to a notion of embodiment or rather 
embodied consciousness. In attempting to create a hermeneutics of embodiment for religious rituals that would conventionally be analysed in terms of possession, I will draw on the Hindu deity Shiva's 'dance of rapture' as well as the notion of embodiment being the existential ground of possibility for culture and self (Csordas 1994: 612). My contention is that this framework is closer to the cultural categories within which such forms of worship are situated. Moreover, it is also from this perspective that a case can be made for understanding 'possession' rituals as being constitutive of knowledge rather than belief.

I will illustrate my arguments with materials gathered from recent preliminary field research into the narratives and rituals of the Central Himalayan deity Goludev. ${ }^{1}$ Goludev is spoken of as the 'God of Justice' and is equally worshipped by both high and low ranked communities (Thakurs, Brahmans, Dalits). Goludev's devotees perceive him to be a manifestation of Bhairava who is the wild and terrifying aspect of Shiva.

\section{GOD OF JUSTICE}

Goludev is worshipped in the northern Indian region of Kumaon. Kumaon is a mountainous region that borders on Nepal in the east and Tibet in the north. To the west lies Garhwal and together they form the recently established Indian state of Uttarakhand (called Uttaranchal between 2000 and 2007) which means 'northern region' or 'land of the north.' ${ }^{2}$ Kumaonis often refer to their region as Dev Bhumi or 'Land of Gods' or 'Divine Earth'. Indeed many powerful gods and goddess reside here along the banks of sacred rivers and on the snow covered mountain peaks. Some of these gods, like Lord Shiva, are known beyond the boundaries of the region. Other gods, however, specially belong to Kumaon. Certain regional deities, like Gangnath and Saim Dev are supposed to have initially travelled to Kumaon from Nepal but now they are very much rooted in the earth and culture of Kumaon. A number of these gods are present in hillside shrines in villages and in rituals of embodiment in which they enter and speak through the bodies of sensitive 'dancers' (nacnevala) during intense 'awakening' sessions (jagar). There are other long processions and antagonistic rituals also in which gods and goddesses are appeased, awakened and made present for all to see and participate in. Each god and goddess has his or her own story of how he or she 'originated' and came to reside at a particular place. While each deity is strong and effective in dealing with issues that face devotees, Kumaonis gently assert that there is a hierarchy amongst these 'Kumaoni' deities. There is one deity who is the most powerful of all regional deities whose origin - unlike other significant regional deities who have come from 
Nepal - lies in Kumaon itself.

When I visited the region briefly for the first time in December 2004, I was informed by several people that Goludev was the most powerful deity in Kumaon without whose intervention nothing would work. I was told that he was a granter of all wishes and that he presided specifically over matters of justice (nyay). In fact, his juristic authority is considered greater than the authority of civil courts in the region. I was informed on several occasions, for example, that if someone involved in a civil suit threatens to take a petition to Goludev, the party in the wrong would quickly back down and admit to being in the wrong rather than have Goludev deal with the matter This particular connection to justice is derived from Goludev's own experience of injustice as a child. As the only son of a king, his step-mothers attempt, unsuccessfully, to kill him several times. Finally, he is abandoned by them in a box to float down a river. A childless fisherman catches the box in his net. Goludev is raised by his humble foster parents until as a young boy he confronts his step-mothers and proves to the king that he is his son. The step-mothers are punished and Goludev and his mother are given their rightful place in the kingdom. When he ascends the throne he takes it upon himself to conduct tours of all the villages and towns in his kingdom making sure that his subjects' concerns are heard and that justice is established in his kingdom of Kumaon. ${ }^{4}$

Goludev's devotees are able to solicit his mediation or intervention in matters of justice (a category used in this context to cover a wide-range of life concerns) in two predominant ways. The first way of requesting his mediation is through the submission of written petitions (manauti) ${ }^{5}$ in his main temples at Chittai (near Almora) and Ghoda Khal (near Bhavali). These temples are administered by Brahman priests of the Panth and Joshi lineages respectively ${ }^{6}$, and are described as 'courts of justice' (kaccheri). The second manner of soliciting his advice and intervention is through an oracular ritual called jagar. ${ }^{8}$

PETITIONS AND BELLS

The petitions are usually written on official stamp paper and sometimes on blank sheets. These are offered to the deity in his temple where they are hung together with hundreds of brass bells that are offered to the deity if the petitions are successfully dealt with. ${ }^{9}$ The petitioners concerns are varied covering several life areas: Problems arising from land-ownership and property; success in examinations, health, business deals, marriage, divorce, children, mental problems, addiction, enemies, lotteries, elections, success with job applications (see Agrawal 1992). 
Besides the submission of petitions and the jagar ritual that I will discuss in more detail below, there are also several other instances outside this established framework through which the deity manifests his power and agency. Examples of these are to be found in written and oral narratives and anecdotal material.

One such example that illustrates the deity's power outside the context of petitions or rituals of embodiment is to be found in a narrative concerning the history of one of Goludev's main temples situated in Ghoda Khal. This story was related to me by the chief priest of this temple as he showed me around the temple and its compound. In one of the three thick branches of a threepronged oak tree near the main shrine, ${ }^{10}$ as the branch bends half way before turning to reach straight up into the sky, he pointed to a strange shiny object. The tree has somehow grown over it and only a part of its gleaming metallic body protrudes from the gnarled elbow of the branch. It is a brass bell. It is one of the thousands of brass bells festooning the temple grounds that were gifted to the god by devotees who have had their petitions fulfilled. Why was this bell in the tree so important as to be singled out by the priest from the other thousands? According to the priest, this was the first bell that was gifted to Goludev. It was gifted by General Patrick Wheeler who in the latter half of the nineteenth century was entrusted with the estate of Ghoda Khal, the area where this important temple of Goludev is situated. General Patrick Wheeler was the son of General Hugh Wheeler who died in the city of Kanpur during the so-called 'Sepoy Mutiny' of 1857 . Patrick Wheeler's grave is in a cemetery in the town of Bhawali not far from the temple of Goludev in Ghoda Khal. According to the chief priest:

The estate of Ghoda Khal belonged to General Wheeler. He wanted to build his bungalow up on the hill where the temple of Goludev is situated. This was the best place in the estate high up on the hill with stunning views of the surroundings. During that time the temple was looked after by a priest from Nepal whose name was Puran Mal. Puran Mal practiced Tantric rituals here and was a devotee of (Lord) Bhairava. General Wheeler came over to Puran Mal and said: 'What's all this here? What's with all the singing and blowing into conch shells?' Well, the General was a Christian and didn't have any idea of what was going on. He began to attack Puran Mal. He tried violently to remove him from the place. He even went so far as to order his men to shoot Puran Mal. But he couldn't harm Puran Mal in any way. Then Puran Mal laid a curse on him that he should have no children. The General went home and over there strange things 
began to happen. While he slept, his bed flew up and he found himself below the bed. The same thing happened to his wife. And, of course, they didn't have any children. Finally, the General visited the temple and accepted the power and authority of Goludev. As a sign of his acceptance he made Goludev the gift of a brass bell. Since then people make Goludev the gift of bells.

Devotees of Goludev follow the example of General Wheeler of gifting brass bells to the god. Is there something significant in this example? Does Goludev's victory over the General perhaps represent a victory over colonial authority by the regional deity? Or is the story of General Wheeler but one instance of the kind of justice that Goludev executes?

The story of General Wheeler and Goludev, it would seem, is expressive of the encounter and conflict between the symbols and instances of local (divine and religious) power and non-local or non-regional (secular, modern, worldly) power. What is at stake here is, it would appear, the question of efficacy and power. While General Wheeler - although he has the backing of the entire colonial apparatus behind him - remains powerless in driving out Puran Mal, Goludev is rapidly able to transform the General into affirming and accepting a higher, divine authority. The story of General Wheeler is also significant because it represents a particularly important moment in the history of the worship of Goludev. It is in the encounter with colonial power and with modernity that, according to the priest of the temple, one of the central ritual and performative practices in temples is established: the gifting of brass bells to Goludev. Thus while the example of General Wheeler can be viewed as representing an instance of religious 'conversion', it also represents the inclusion or encompassment of an 'outside' intervention into the ritual practice and religious history of Goludev.

JAGAR

The second important manner, besides petitions, in which Goludev deals with matters of justice (and indeed healing in a broader sense) is through what may, in conventional terms, be described as an oracular trance ritual, but what I will refer to here as a ritual of embodiment called jagar. In attempting to create a hermeneutics of embodiment for religious rituals that would conventionally be analysed in terms of possession, I will draw here on the myth of the Hindu deity Shiva's 'dance of rapture'11 and on the notion of embodiment being the existential ground of possibility for culture and self (Csordas 1990). 
Jagar means 'waking', 'staying awake', and is sometimes translated as 'night vigil.' ${ }^{2}$ The jagar can therefore be described as an intense ritual of 'awakening' for both deity and devotees. Monika Krengel in her essay on the jagar notes its complex nature:

It is not possible to single out one aspect, e.g. curing, healing, psychological effects, without taking others, such as integration, dealing with uncertainties, and the definition of justice and responsibility into account. All relevant memories, rules, deviations and expectations are encapsulated in the institution of jagar, which potentially affords a bird's eye view of being that transcends present social and political action (Krengel 1999: 281).

The jagar usually has four chronologically structured sections. In the first, which is called 'sandhya' ('Evensong'), several regional and supra-regional deities are mentioned and praised. ${ }^{13}$ In the second section Goludev is invoked by narrating his life-story. ${ }^{14}$ In the third section the deity responds to the questions and concerns that are put to him by devotees gathered for the ritual. The fourth and final section involves the release of the deity and the conclusion of the ritual. ${ }^{15}$ The jagar has two main actors: a singer or bard called the jagariya (literally 'awakener') and the person entering into a so-called trance who is called the dangariya. Both jagariya and dangariya, in contrast to the high-caste priests of the larger temples of Goludev, may often, though not exclusively, belong to low-caste Dalit communities. The dangariya is, more importantly for the questions raised earlier regarding embodiment and embodied consciousness, also called nacnevala or the 'one who dances', 'one who possesses dance' (i.e. the dancer).$^{16}$ Similar to the case of written petitions handed to the god in his temples, the concerns of devotees here can vary, often though the ritual is used to establish the hidden cause of illness, misfortune or injustice (see Krengel 1999, Leavitt 1997). Jagars are most often performed in the environment of a devotee's home into which the singer and dancer are invited. Immediate family members but also wider public from the village participate as the audience.

\section{Representational and Non-Representational Speech}

While the speech of the jagariya or singer follows certain narrative patterns ${ }^{17}$ - often the singer narrates the biography of Goludev and other deities - the speech of the nacnevala or dancer is often fragmented or broken and supposedly incomprehensible. The use of language in the case of the singer is discursive and representational. ${ }^{18}$ By narrating the story of Goludev, the singer is able to recreate or re-presence the past in the present. And, by doing that he 
is able to re-establish the territory of Kumaon and Goludev's place within it as a God-King of justice. The speech of the dancer on the other hand is nonrepresentational: his fragmentary utterances are the words of Goludev and there is no distinction between the deity's words and himself. To make a further distinction drawn from the work of Merleau-Ponty (see Csordas 1993: 152): the jagariya or singer's world is one of the 'spoken' word that is discursive and dualistic in nature; the nacnevala or dancer's world on the other hand, is one of the 'speaking' word that is non-discursive and non-dualistic. Language in the latter case has, in a very fundamental sense, an existential, somatic meaning.

\section{Shiva's Dance of Rapture}

One of the most celebrated forms of Shiva - particularly in south India-is Nataraja: King or Lord of Dance. ${ }^{19}$ Shiva dances the 'dance of rapture', the ananda-tandava. The dance has 'unsettling connotations of wildness and destruction' (Shulman and Handelman 2004:1), signifying the end of the world. Although the narrative of Shiva's emergence as dancer and its iconographic representation is 'the most salient of his forms in south India' (Shulman and Handelman 2004:1), the story of the God becoming a dancer is, paradoxically, located in northern India in a Himalayan pine forest. My intention, in the context of this paper, is to 'pay attention' to the phenomenon of dance as a critical mode of embodied consciousness. I use the notion of 'paying attention' in the sense outlined by the French phenomenologist and existentialist philosopher Merleau-Ponty: 'To pay attention is not merely further to elucidate pre-existing data, it is to bring about a new articulation of them ... attention is ... the active constitution of a new object which makes explicit and articulate what was until then presented as no more than an indeterminate horizon' (Merleau-Ponty 1962:30, cited in Csordas 1993:135).

Let us look briefly here at what happens in the south Indian telling of the story of Shiva entering the Forest of Pines:

[The] god wanders into a forest of Himalayan pine trees and becomes lost. Human beings of varying degrees of taste and discernment, inhabit this forest and encounter this god. The meeting changes both parties. The human side, in its male aspect, begins to experience, through hate, something that could be called love, perhaps for the first time. The female aspect, freed from shame or restraint, turns fertile and generative. The god becomes more alive, which is to say, more full of self, more present, in deeper or more rapid movement. Deeper - since this is a process of involution and 
spin that takes the visible form of dance. This internal movement within the god and his cosmos is also, however, an exorcism, unlocking the ensorcelled pieces of self (Shulman and Handelman 2004:1).

Why does God dance? He dances, perhaps, to unfreeze aspects of himself that have somehow become solidified, rigid, frozen and ignorant. Dance becomes a mode of movement that results in self-knowledge even for God and, of course, for those who observe and participate in his dance. In the story of Shiva entering the Forest of Pines, the sages dwelling in the forest experience a hatred for Shiva that arises out of an ignorance of who he really is - they create an evil fire from which a variety of creatures and objects emerge with the aim of destroying the God. The final 'weapon' they hurl at him is the demon called Apasmara (Tamil: Muyalakan) - the demon of epilepsy. Confronted by this demon of epilepsy and of the forgetting of Self, Shiva steps onto the creature's back and breaks its spine: '...And as the creature moved, slowly, gingerly lifting its head, Siva took that as reason to dance - and danced, as if forever. It was that moment, and at that place, that the god of three eyes began his tandava dance, as the whole world shuddered' (Shulman and Handelman 2004: 14).

\section{Dance and Self-knowledge}

Again, we have here the question of self-knowledge and of re-connectivity. Why is dance so crucial to the moment of re-connectivity and of self-knowledge? What is dance and what happens through it? Dance, primarily is a mode of doing with the body. But as the story of Shiva in the Forest of Pines makes clear, it is in a primary manner not just a mode of doing with the body, it is also a mode of knowing by doing through the body. It is a knowledge that arises somatically within and through the body. As Martha Graham, writing in another context, says: 'Dance is absolute. It is not knowledge about something, but is knowledge itself' (Martha Graham, cited in Morgan 1980 [1941]:11). Knowledge of self therefore arises through the movement of dance as self-knowledge that is embodied. Diedre Sklar writes of movement 'as felt experience, as kinesthesia. Movement, she says, is:

unique among media of expression. In other media, the mode of production is different from the mode of reception. We produce sound kinaesthetically, via muscular movement, but we hear it aurally; we paint kinaesthetically but review it visually. In movement one does and feels oneself doing at the same time... Awareness of experiencing what one is expressing is the kind of somatic transformation emphasized by disciplines like yoga or breathing meditation. 
It is the ultimate intimacy, a doing while being with oneself... This way of apprehending might be called 'dropping down into the body', (or redirecting a phrase from Thomas Csordas) 'a somatic mode of attention... To attend in somatic mode is to apprehend, as felt experience, the kinetic dynamics inherent in movements, images, and sounds (Sklar 2000:72).

There are several scholarly studies on classical and folk dance traditions in India. The Sanskrit word Natya, to which Nrtya (dance) is related, suggests drama or performance but also architecture, dance, music, poetry and painting. As Kapila Vatsyayan notes, Natya in its classical sense, is 'not an aggregation of disciplines. It is an interpenetration of disciplines ... an integral multi-disciplinary approach.' (Vatsyayan 1996: 45). Anthropological studies of social and ritual behaviour in different regions of India involving dance (Teyyam, Pandava Nrtya, 'possession' rituals) focus on dance in the context of narrative, performance, belief, articulations of social hierarchies, ritual etc. 'Spirit possession' whether in a highly choreographed form or in a spontaneous form also can involve dance or dance-like movement. ${ }^{20}$ However, even while 'dance' is analysed from a textual perspective ${ }^{21}$ or invoked in studies involving field research, there is scant attention paid to the phenomenology of dance as an embodied instance of consciousness and knowledge (exceptions being Vatsyayan and Coomaraswamy). Although dance is mentioned, even profusely, in scholarly studies, its treatment, it seems to me, is almost casual, cursory in a manner of being taken for granted. Scholarly literature abounds with phrases similar to the following: 'then the group dances together', 'the spirit medium begins to dance,' 'the singer moves his body in a dance-like manner', 'devotees sway and dance while possessed. For the most part, however, the attention given to the choice of language, the metaphor and actual activity of dance in religious behaviour and rituals in India is often confined to an analysis of the symbolism of choreographed movement in different performative situations.

Furthermore, if, as Thomas Csordas (1990:40; 1993:135) maintains, embodiment is the existential ground for culture and embodied experience the starting point for understanding human participation in a cultural world, then dance, I would like to suggest, in several instances of religious ritual, is a primary way of 'being-in-the-world'. Dance, as embodied movement, is a 'mode of praxis' (to borrow a term from Bourdieu), so to speak, of consciousness itself. 
During the jagar the singer and the dancer create what can be termed a discursive and poetical world of knowledge, and not one of 'belief', through the use of different kinds of speech. The question that arises here is: What is the relationship, in the context of the jagar, between the discursive, representational word of the jagariya or singer and the non-discursive, non-representational word of the nacnevala or dancer? It would appear that discursive, representational speech or language is used to cause non-discursive, non-representational language to arise. Non-representational language is, in this case, by its very nature somatic, 'incarnate' or embodied. There is no distinction, as I have mentioned, between the deity, his body and his speech. But what does it mean to say the dual or representational causes the non-dual or non-representational to come into existence? Is it sufficient to describe the relationship between the dual and the non-dual in terms of cause and effect? Or can we speak here of a dialogic inter-wovenness or interdependence of the 'pre-objective' (non-dual) and the 'objective' (dual) (in Merleau-Ponty's sense) in which the objective articulates and expresses the pre-objective? And that, in this sense, the sequence suggested, for example, by Merleau-Ponty of moving from the pre-objective figure to the objective figure, is in fact reversed: It is the objective that calls forth the pre-objective into existence. The singer uses language, narrative, song, and sound through a drum (hurki) and metal plate (thali) to cause the embodiment of the deity. The speech uttered by the deity is of another order though. His speech causes justice and healing to take place. In the jagar therefore, the discourse created by the narrative texts and utterances of the singer and the dancer bring forth an extra-ordinary poetical world which establishes the efficacy, agency and presence of Goludev.

The deity is however, for the period of the jagar, a dancer. His actions are referred to as dance and his presence is felt through movement (and speech). In other words his presence is embodied through the movement of dance. Particularly important here, I think, is the concept of the avatar which defines the language of embodiment. The dancer is simultaneously also an avatar or 'incarnation', 'descent', 'embodiment' of Goludev. And, Goludev himself, as I mentioned before, is an avatar of Bhairava, the wild and dangerous aspect of Shiva. Goludev is Bhairava, the wild manifestation of Shiva, who on a deep level simply is pure consciousness. Consciousness, however, does not exist in a disembodied form or in the dual (Cartesian) world of Mind and Body. As the notion of the avatar demonstrates, consciousness exists primarily in a series of embodiments: Shiva is embodied in Bhairava who is embodied in Goludev who furthermore is embodied in the nacnevala or dancer. And, as I 
pointed out earlier, central to Shiva's manifestation in the story of his journey into the Forest of Pines, is his 'dance of rapture'. As a moment of recovery of self-knowledge, ${ }^{22}$ this dance is, in a fundamental manner, a mode of being-inthe-world that validates the paradigm of embodiment (Csordas 1990).

My contention here is that the jagar can be more fruitfully described as a ritual of embodiment rather than a ritual of possession or trance - since the category of possession itself carries within it a considerable amount of cultural bias and theoretical implications suggesting a duality of body and consciousness or spirit. In the language of possession, spirit or consciousness can exist separate to the body. In fact, possession suggests the taking possession of a body by spirit or consciousness. Embodiment on the other hand emphasises '...subjectivity as a self-world relation rather than as consciousness apart from the world... (in this context) the lived body is this relation ... that crosses subjectivity and objectivity' (Morley 2001:75). The dancer, in the case of the jagar, by embodying God represents the 'relation between subject and world that is prior to their categorical division.' (Morley 2001:74). The dancer in the jagar is an embodiment of Bhairava or Shiva who is, on a fundamental level, pure consciousness. Dance, is, in the case of the jagar as well of Shiva in the Forest of Pines, the critical mode of embodiment that pure consciousness chooses in order to know itself fully. And, it is through this form of doing with the body therefore that self-knowledge and with it the possibility of healing and administering justice arises. It is in this sense that we can speak of a system of 'knowledge and practices' rather than 'belief and practices' in which the deity is a powerful, active agent, whose power arises with the creation of embodied knowledge, (and not with the occurrence of spirit 'possession'), through the use of both representational and non-representational language and movement or 'dance'.

NOTES

1 Goludev is known also by several other names: Goljyu, Goriya, Goril, Gvalldev, Gvelldev, and Gola Baba.

2 See Linkenbach (2007: 27f.). Uttarakhand was established in November 2000 as a new state in the Indian Union after splitting itself off politically from the large northern Indian state of Uttar Pradesh.

3 The existence of a deity who presides over nearly the entire territory of Kumaon is distinct from the case of the bordering division of Garhwal in which there are several powerful deities (for example, the four Mahasu brothers) who maintain 
'control' over different sub-territories within the region but not over the region as a whole.

4 The narrative of Goludev's life is told during the jagar ritual that I discuss below. In the concluding sections of the narrative there is mention of different villages and sub-regions of Kumaon to which Goludev is called to in order to attend to injustices. Sometimes this involves his subduing other divine or human forces.

5 Although written petitions are the most tangible and visible forms of manautis, petitions or requests for the fulfilment of wishes and desires can also be made in an interior, 'mental' manner.

6 Priests of the Panth lineage claim to have migrated together with their deity from the western Indian region of Maharashtra some generations ago.

7 The temple at Ghoda Khal has also become the location for marriage ceremonies, particularly for couples who do not have the endorsement of their families by virtue, for example, of belonging to different social backgrounds (i.e. castes) or religious communities (eg. Hindu and Sikh). On such occasions the priest is able to administer a marriage certificate for the bride and bride-groom for which Goludev acts as witness. The certificate issued by the priest is legally binding and once it is handed in to a civil court, a state endorsed marriage certificate must be issued by court authorities.

8 The bulk of this essay will be concerned with an interpretation of the jagar, as my research has progressed more in that direction rather than on petitions.

9 See below for the historical origin and ritual significance of the gifting of bells.

10 The three-pronged oak tree has symbolic significance within the ritual layout of the temple, since Shiva, of whom Goludev is a manifestation, has, as one of his emblems, a trishul or trident.

11 Goludev's devotees perceive him to be a manifestation of Bhairava who is the wild and terrifying aspect of Shiva.

12 There are several different kinds of jagars. See Krengel (1999).

13 See Leavitt (1997) for a detailed discussion of the 'Evensong' as well the other parts of the jagar. 
14 The manifestation of Goludev is brought on or even accelerated by the emotions of anger ('gussa') and passion ('josh') that the deity experiences particularly when instances of injustice from his life are retold. This second section is also specially referred to as the jagar since it involves the most potent awakening of the deity. Thus, even though the deity is manifest from the very commencement of the ritual, it is only after this second 'phase' of the jagar that the deity is in a position to articulate the insights and responses that he will provide to the gathering of devotees.

15 This concluding part of the jagar is critical, since if it is not conducted properly, the dangariya (see below) will remain in a kind of embodied 'limbo'.

16 See also below. The dangariya can also be called devta ka ghoda ('deity's horse'). See Agrawal (1992:37, fn. 6).

17 Both the sandhya and 'jagar' sections can be expanded or contracted by the singer to suit the requirements of a particular ritual and its sponsors.

18 The use of language to create a discursive or mythic universe '.. not only refers to a concrete situation but to reality which is independent of a specific context... ritual speech in general implies and constructs a particular vision of the universe in which the speaker acts and interacts...it does not simply reflect a preexisting social and cosmological order, but actively recreates it through repeated performances' (Gaenszle 2002:13-14).

19 See Coomaraswamy (1924); Kramrisch (1981:440) describes Shiva as the lord of dance in the following passage: “...Nataraja, the lord of dancers, dancing, shows his fivefold activity, the expression of his divine totality. His dancing limbs convey by their movements and symbols the fivefold action of creation, maintenance, dissolution, veiling-unveiling, and liberation. Nataraja dances the cosmos into existence, upholds existence, and dances it out of existence."

20 Recent publications point to the centrality of dance: William Sax's work entitled 'Dancing the Self' (2002) or Martin Gaenszle's forthcoming article entitled 'Dancing to the origins' and of course the title of this essay.

21 In the case of classical Indian dance, for example, by Vatsyayan (1996), Coomaraswamy (1924).

22 Or of Being; see Kersenboom, (1995:71) on 'recovery of being' versus 'recovery of meaning. 


\section{REFERENCES}

Agrawal, C.M. 1992 Golu Devata: The God of Justice of Kumaon Himalayas, Almora: Shree Almora Book Depot.

Coomaraswamy, A. 1924 The Dance of Śiva. New York: The Sunwise Turn.

Csordas, T.J. 1990 'Embodiment as a paradigm for anthropology', Ethos 18(1): 5-47.

Csordas, T.J. 1993 'Somatic modes of attention', Cultural Anthropology 8(2): 135-156.

Freeman, R. 1993 'Performing possession: Ritual and consciousness in the Teyyam complex of Northern Kerala', in H. Brückner, L. Lutze and A. Malik (eds) Flags of Fame: Studies in South Asian Folk Culture, Delhi: Manohar Publishers.

Gaenszle, M. 2002 Ancestral Voices: Oral Ritual Texts and their Social Contexts Among the Mewahang Rai of East Nepal, Münster: LIT Verlag.

— forthcoming 'Dancing to the origins', in C. Brosius and U. Huesken (eds) Ritual Matters, New Delhi: Routledge.

Kersenboom, S. 1995 Word, Sound, Image: The Life of the Tamil Text, London: Berg.

Kramrisch, S. 1981 The Presence of Śiva, Princeton: Princeton University Press.

Krengel, M. 1999 'Spirit Possession in the Central Himalayas. Jagar-Rituals: An Expression of Customs and Rights', in J. Assayag, and G. Tarabout (eds) Possession in South Asia: Speech, Body, Territory, Collection Purusartha, (21):265-288.

Leavitt, J. (ed) 1997 Poetry and Prophecy: The Anthropology of Inspiration, Ann Arbor: University of Michigan Press.

Linkenbach, A. 2007 Forest Futures: Global Representations and Ground Realities in the Himalayas, Ranikhet: Permanent Black.

Morgan, B. 1980 [1941] Martha Graham: Sixteen Dances in Photographs, Dobs Ferry: Morgan and Morgan. 
Morley, J. 2001 'Inspiration and expiration: Yoga practice through Merleau-Ponty's phenomenology of the body', Philosophy East and West. 51(1):73-82.

Sax, W. 2002 Dancing the Self: Personhood and Performance in the Pandav Lila of Garhwal, New York: Oxford University Press.

Schömbucher, E. 1993 'Gosts, gods, and demons: Possession in South Asia', in H. Brückner, L. Lutze and A. Malik (eds) Flags of Fame: Studies in South Asian Folk Culture, Delhi: Manohar Publishers.

2006 Wo Götter durch Menschen sprechen: Besessenheit in Indien, Berlin: Dietrich Reimer Verlag.

Shulman, D., D. Handelman 2004 Siva in the Forest of Pines. An essay on sorcery and self-knowledge, New Delhi: Oxford University Press.

Sklar, D. 2000 'Reprise: On dance ethnography', Dance Research Journal, 32(1): 7077.

Vatsyayan, K. 1996 Bharata: The Natyasastra, New Delhi: Sahitya Academy.

Ziegenbalg, B. 1926 [1711] Malabarisches Heidenthum, W. Caland (ed), Amsterdam: Koninklijke Akademie van Wetenschappen. 